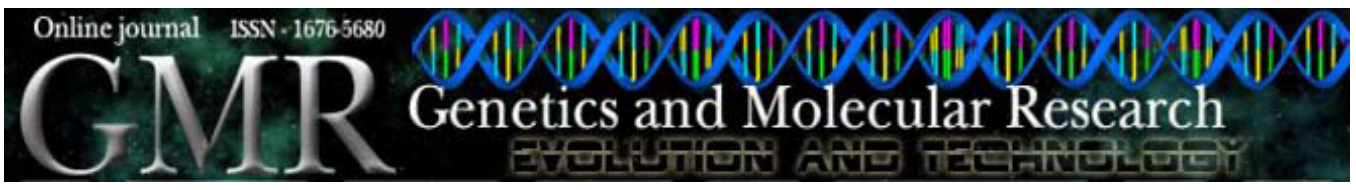

\title{
Proteomics-based approach for identification and purification of human phosphate binding apolipoprotein from amniotic fluid
}

\author{
M. Alam ${ }^{1}$, M. Mahajan' ${ }^{1}$ M. Raziuddin' ${ }^{2}$, T.P. Singh ${ }^{1}$ and S. Yadav ${ }^{1}$ \\ 'Department of Biophysics, All India Institute of Medical Sciences, \\ New Delhi, India \\ ${ }^{2}$ Department of Zoology, Vinoba Bhave University, Hazaribag, India \\ Corresponding author: S. Yadav \\ E-mail: savita11@gmail.com
}

Genet. Mol. Res. 8 (3): 929-937 (2009)

Received March 27, 2009

Accepted June 4, 2009

Published August 4, 2009

\begin{abstract}
Human amniotic fluid is of both maternal and fetal origin; it protects the fetus and provides the environment for growth and development of the fetus. We used a proteomics-based approach for targeting and purifying human phosphate binding protein, a member of the DING family of proteins from amniotic fluid, using Blue Sepharose CL-6B, DEAE-Sephacel and gel filtration chromatography. The protein had earlier been reported to be serendipitously purified along with PON1 (paraoxonase 1). It was identified using electro-spray-ionization-time-of-flight mass spectrometry and was found to be human phosphate binding protein. Human phosphate binding proteins have been reported to play a role as phosphate scavengers and may have a protective function against phosphate-related disorders, such as atherosclerosis, diabetes and kidney stones.
\end{abstract}

Key words: Amniotic fluid; Human phosphate binding protein; Proteomics 


\section{INTRODUCTION}

Human amniotic fluid is a protein-rich fluid formed from maternal blood ultrafiltration by the placenta and excretion from the fetus urine (Lotgering and Wallenburg, 1986). Human amniotic fluid has been shown to contain 412 proteins, as found by MALDI-MS and MALDIMS-MS (Tsangaris et al., 2006), which are either fetal or maternal in origin (Campbell and Lees, 2000). Apart from the physical environment, which protects the growing fetus (Verburg et al., 2007), amniotic fluid also provides constituents essential for fetal growth and well-being (Strong Jr. et al., 1990; Whitfield and Ritche, 1995), in which proteins play an important part (Chevallier et al., 1998; Heizmann, 1999; Tsangaris et al., 2006). Human phosphate binding protein (HPBP) is an apolipoprotein, 38-45-kDa glycosylated protein, found mainly in plasma (Renault et al., 2006) and also in human amniotic fluid (Tsangaris et al., 2006). HPBP was first purified by chance along with PON1. HPBP is a member of the DING family, which suggests its distribution in a wide number of eukaryotes (Morales et al., 2006, 2007). The DING protein family seems to have emerged by consensus for ubiquitous but genetically elusive proteins, usually with a molecular weight of around $40 \mathrm{kDa}$, of which the $\mathrm{N}$-terminal sequence is DINGGG- (Adams et al., 2002). HPBP plays a key role, being identified as the first transporter to bind phosphate ions in human plasma (Berna et al., 2008), and it helps in the function of PON1 (Rochu et al., 2007a). HPBP is also known to stabilize the PON1 and high-density lipoprotein association (Rochu et al., 2007b) and promotes phosphotriesterase activity (Rochu et al., 2007a). Both HPBP and PON1 associated with high-density lipoprotein (Harel et al., 2004) are governed by plasma calcium and phosphate concentrations (Fokine et al., 2003) and work in tandem to reduce the risk of phosphate-dependent diseases such as athrosclerosis (Schmidt et al., 1998), diabetes (Dursun et al., 2006) and kidney stones (Kumar et al., 2004).

We purified HPBP from human amniotic fluid using a proteomics-based approach to target protein on the basis of molecular weight and pI, as evident on the 2-D gel map. The role of HPBP in amniotic fluid is still not clear, but its role in fetal development and well-being will be interesting none the less.

\section{MATERIAL AND METHODS}

Samples of $5 \mathrm{~mL}$ amniotic fluid each from 5 documented $\mathrm{Rh}$-sensitized pregnancies at the 24th-36th week of gestation were pooled, which were planned from amniocentesis to evaluate other gestational diseases. The specimens were obtained from the Department of Obstetrics and Gynecology, All India Institute of Medical Sciences, New Delhi, after obtaining written informed consent from the patients. The study was approved by the university Ethics Committee (Ref. No. A-16/25.07.2007).

\section{Method of sample collection}

Detailed ultrasound was performed to delineate fetal heart rate, site of placenta, amount of fluid, and any gross fetal malformation. The patients were placed in lithotomic position and their lower abdomen was cleaned with antiseptic solution. A 23-G spinal needle was used to aspirate the amniotic fluid per abdomen under ultrasonic guidance by a medical professional specialized in the field of prenatal diagnostic procedures and fetal medicine. The first 
$1 \mathrm{~mL}$ amniotic fluid was discarded, and then $5 \mathrm{~mL}$ amniotic fluid was drawn. Samples were centrifuged at 20,000 $\mathrm{g}$ for $30 \mathrm{~min}$, and the supernatant was used for different experimentation.

\section{Standardization of samples}

Each sample was scanned by UV spectroscopy and a Lilly chart was obtained to establish whether the pregnancy was $\mathrm{Rh}$-isoimmunized. Samples were stored at $-20^{\circ} \mathrm{C}$ until further use.

\section{Albumin removal by Blue Sepharose CL-6B chromatography}

Albumin, which comprises more than $50 \%$ of the protein content of amniotic fluid, tends to mask the other proteins, which are over-expressed, giving rise to false-negative results. Hence, albumin needs to be removed before loading the sample on the IPG strip. To address this problem, the pooled samples were submitted to albumin depletion using Blue Sepharose CL6B affinity chromatography. The sample was first centrifuged at 20,000 $\mathrm{g}$ for $30 \mathrm{~min}$. The supernatant was collected and mixed with equilibrating buffer $(0.05 \mathrm{M}$ Tris- $\mathrm{HCl}, \mathrm{pH} 8.0)$ before loading onto a Blue Sepharose CL-6B (Amersham Biosciences) column $(2.6 \times 20 \mathrm{~cm})$. Passing of amniotic fluid through a column of Blue Sepharose CL-6B column results in the removal of approximately 60 to $70 \%$ of the albumin (Travis et al., 1976; Angal and Dean, 1977).

\section{Precipitation of protein for 2-D gel electrophoresis}

Proteins from the unbound fraction of Blue Sepharose CL-6B were precipitated using 9 $\mathrm{mL} 0.05 \mathrm{M}$ Tris- $\mathrm{HCl}$ buffer, $\mathrm{pH} 8.0$, and $2 \%$ protease inhibitor cocktail solution [1 mM 4-(2-aminoethyl) benzenesulfonyl fluoride, $1 \mathrm{mM}$ EDTA, $130 \mathrm{mM}$ bestatin, $14 \mu \mathrm{M} \mathrm{E}-64,1 \mathrm{mM}$ leupeptin, $0.3 \mu \mathrm{M}$ aprotinin]. After incubation at $-20^{\circ} \mathrm{C}$ for $2 \mathrm{~h}$, the mixture was vortexed, cooled on ice repeatedly, and then centrifuged at $15,000 \mathrm{~g}$ for $15 \mathrm{~min}$ at $4^{\circ} \mathrm{C}$. Cold acetone was added to the supernatant to a final concentration of $80 \%, \mathrm{v} / \mathrm{v}$, and the mixture was kept at $4^{\circ} \mathrm{C}$ for $1 \mathrm{~h}$. After centrifugation, the pellets were washed with $80 \%$ acetone and harvested again by centrifugation. The precipitate obtained was dried and solubilized in $0.5 \mathrm{~mL}$ lysis buffer (6 M urea, $2 \mathrm{M}$ thiourea, $2 \%$ (w/v) CHAPS, $0.5 \%$ (w/v) Triton X-100, 40 mM Tris-HCl, 50 mM DTT, 0.2\% pH 3-10 Bio-Lyte). The solution was centrifuged at $15,000 \mathrm{~g}$ at $4^{\circ} \mathrm{C}$ for $15 \mathrm{~min}$ to obtain the soluble protein in the supernatant (Park et al., 2006). Protein was determined by the Bradford method (Bradford, 1976).

\section{2-D gel electrophoresis}

\section{Rehydration of IPG strips}

Precast IPG strips with nonlinear immobilized $\mathrm{pH}$ 3-10 gradient were rehydrated overnight with a $1000-\mu \mathrm{g}$ protein sample complemented with $0.0025 \%(\mathrm{v} / \mathrm{v})$ bromophenol blue and 1\% (v/v) IPG buffer (Rabilloud et al., 1994).

\section{Isoelectric focusing}

Isoelectric focusing was performed using the IPGphor ${ }^{\mathrm{TM}}$ IEF system (Amersham Bio- 
sciences): $100 \mathrm{~V} / \mathrm{h}, 300 \mathrm{~V} / \mathrm{h}, 500 \mathrm{~V} / \mathrm{h}, 1000 \mathrm{~V} / 2 \mathrm{~h}$, linear gradient from 1000 to $8000 \mathrm{~V}$, and a final phase at $8000 \mathrm{~V}$ for $12 \mathrm{~h}$, resulting in a total of 100,000 V/h (Gorg et al., 1991). Strips were equilibrated for $10 \mathrm{~min}$ in $9 \mathrm{M}$ urea, $50 \mathrm{mM}$ Tris- $\mathrm{HCl}$ buffer at $\mathrm{pH} 8.8,30 \%$ (v/v) glycerol, $2 \% \mathrm{SDS}, 0.001 \%(\mathrm{w} / \mathrm{v})$ bromophenol blue and $65 \mathrm{mM}$ DTT, and finally for $15 \mathrm{~min}$ in the same solution except that DTT was replaced by $13.5 \mathrm{mM}$ iodo-acetamide (Gorg et al., 1988, 1997).

\section{SDS-PAGE}

Protein was separated on $12.5 \%$ SDS-polyacrylamide gels at a constant voltage of 50 $\mathrm{V}$ for $2 \mathrm{~h}$ followed by $150 \mathrm{~V}$ for $6 \mathrm{~h}$ at $25^{\circ} \mathrm{C}$, using an Iso-DALT electrophoresis unit (Amersham Biosciences). Gels were stained with colloidal Coomassie blue (G-250).

\section{In-gel digestion and ESI-Q-TOF/MS analysis}

The stained protein bands were excised and incubated $24 \mathrm{~h}$ in water, followed by partial drying and then, washing once with $150 \mu \mathrm{L} \mathrm{50 \%}$ acetonitrile (ACN) in $200 \mathrm{mM}$ ammonium carbonate, $\mathrm{pH} 8.9$, for $20 \mathrm{~min}$ at $30^{\circ} \mathrm{C}$ and twice with $100 \% \mathrm{ACN}$ for 10 min each. The gel was dried in a vacuum drier. Trypsin solution $(20 \mu \mathrm{L} ; 5 \mu \mathrm{g} / \mathrm{mL}$ in $25 \mathrm{mM}$ ammonium bicarbonate) was added to the dried gel and incubated overnight at $37^{\circ} \mathrm{C}$. The resulting peptides were recovered by three extractions with a $100-\mu \mathrm{L}$ solution of $60 \% \mathrm{ACN}$ and $0.1 \%$ TFA at $30^{\circ} \mathrm{C}$. The extracts were combined and concentrated to $20 \mu \mathrm{L}$ in a Speed Vac. At the time of injecting sample in ESI-Q-TOF/MS, $0.1 \%$ formic acid was added to acidify the peptide mixtures, and the ESI-Q-TOF/MS was performed in the positive mode.

\section{Purification and identification}

A total of $100 \mathrm{mg}$ protein from the unbound fraction of Blue Sepharose CL-6B (as done for sample preparation of 2-D gel electrophoresis) was loaded onto a DEAE-Sephacel column $(2.6 \times 16 \mathrm{~cm})$, which was pre-equilibrated with $0.05 \mathrm{M}$ Tris-HCl, $\mathrm{pH}$ 8.0. After adequate washing, a linear gradient of $0.0-0.5 \mathrm{M} \mathrm{NaCl}$, in the same buffer was done. The fractions were collected until the absorbance at $280 \mathrm{~nm}$ was 0.005 . The purification status of proteins was checked at every step using SDS-PAGE. The bound fractions of $0.1 \mathrm{M} \mathrm{NaCl}$, onto a DEAE-Sephacel column, were pooled separately, concentrated and desalted using ultrafiltration with a 3-kDa-cutoff membrane (Millipore). A total of $25 \mathrm{mg}$ lyophilized protein was loaded onto a G-75 Sephadex column $(1.6 \times 125 \mathrm{~cm})$, pre-equilibrated with $0.05 \mathrm{M}$ Tris- $\mathrm{HCl}, 0.2 \mathrm{M} \mathrm{NaCl}$, and fractions were eluted at a flow rate of $0.2 \mathrm{~mL} / \mathrm{min}$. Absorbance was measured at $280 \mathrm{~nm}$. Peak 1 containing proteins was pooled and concentrated by ultrafiltration using a 3-kDa cutoff membrane. SDS-PAGE was performed on 10\% polyacrylamide gels, and proteins were stained with colloidal Coomassie blue (G-250). The single band obtained on SDS-PAGE was excised, trypsin digested and analyzed by ESI-Q-TOF/MS.

\section{RESULTS AND DISCUSSION}

All samples of amniotic fluid used for experimentation were obtained for detection of status of Rh-isoimmunized pregnancy. The Lilly chart was obtained using a UV-visible 
spectrophotometer at $450 \mathrm{~nm}$, and samples with absorbance more than 0.1 were used for proteomics and purification.

Figure 1 depicts the typical Lilly chart for the amniotic fluid. A volume of $25 \mathrm{~mL}$ amniotic fluid pooled from 5 cases of Rh-isoimmunized pregnant mothers was loaded on $40 \mathrm{~mL}$ Blue Sepharose CL-6B $(2.6 \times 20 \mathrm{~cm})$ and eluted with $0-0.5 \mathrm{M} \mathrm{NaCl}$ gradient, and the unbound protein was collected in order to remove excess albumin and immunoglobulins masking the gel, shown in Figure 2 depicting their reduction on SDS-PAGE (10\%).

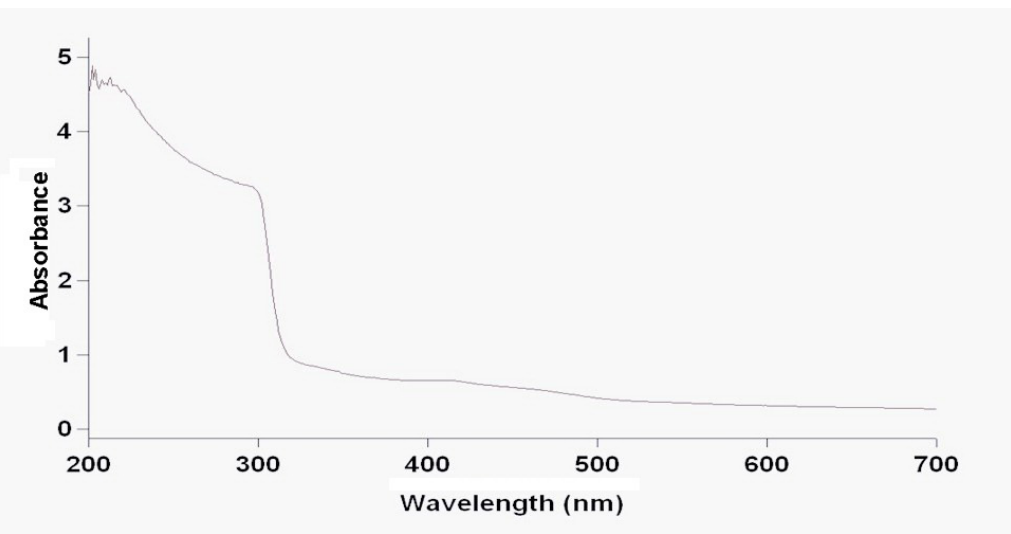

Figure 1. Lilly's chart obtained using UV-visible spectroscopy of amniotic fluid from Rh-isoimmunized pregnancy.

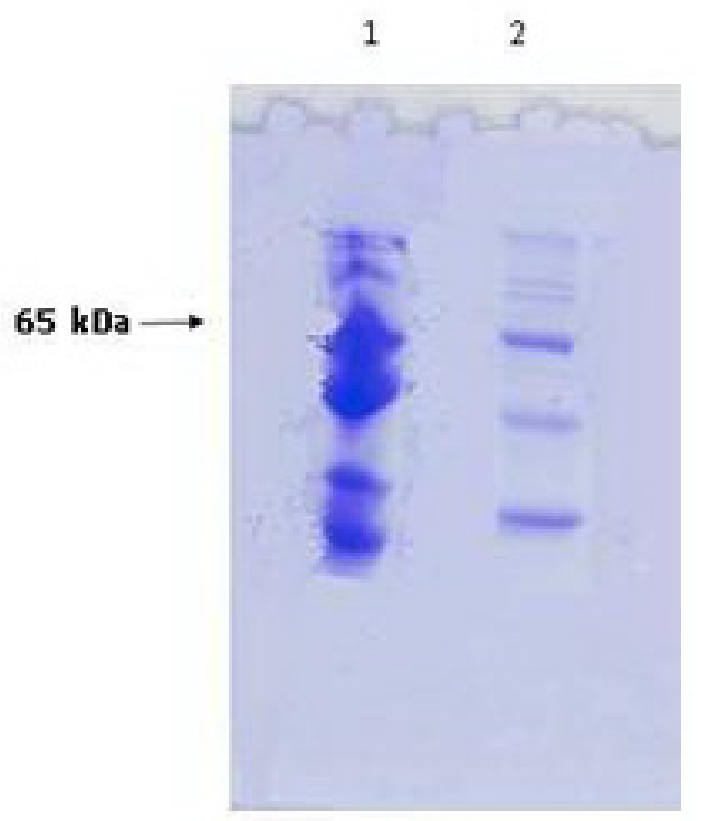

Figure 2. SDS-PAGE (10\%) showing removal of albumin by Blue Sepharose CL-6B on colloidal Coomassie blue (G-250) stained gel. Lane 1 = Crude profile of amniotic fluid. Lane 2 = Unbound fraction from Blue Sepharose CL-6B with decreased content of albumin. 
A total of $1000 \mu \mathrm{g}$ quantified and precipitated protein from the unbound fraction of Blue Sepharose CL-6B was separated to obtain a 2-D gel electrophoresis map, and 35 proteins were identified using ESI-Q-TOF/MS. Figure 3 shows the 2-D gel electrophoresis map of the amniotic fluid and highlights the presence of HPBP in the amniotic fluid.

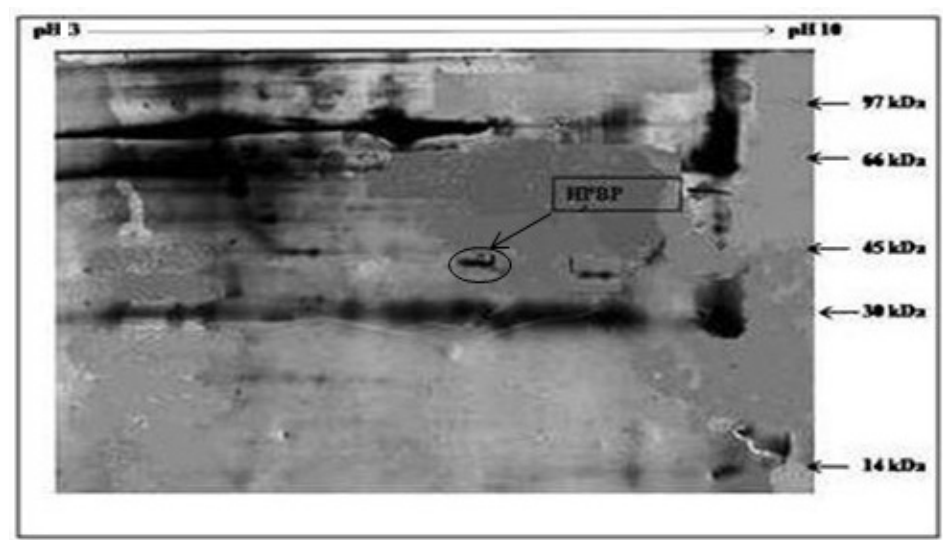

Figure 3. The 2D-gel (12.5\% and $\mathrm{pH} 3-10)$ map from pooled samples of 5 cases of Rh-isoimmunized pregnancy.

The unbound fraction of the Blue Sepharose CL-6B was then loaded onto a DEAESephacel column, which was pre-equilibrated with $0.05 \mathrm{M}$ Tris-HCl, $\mathrm{pH} 8.0$, and eluted with a $0-0.5 \mathrm{M} \mathrm{NaCl}$ gradient. The DEAE-Sephacel bound fraction at $0.1 \mathrm{M} \mathrm{NaCl}$ was pooled separately, concentrated and desalted using ultrafiltration. Figure 4 shows the elution profile of DEAE-Sephacel column chromatography.

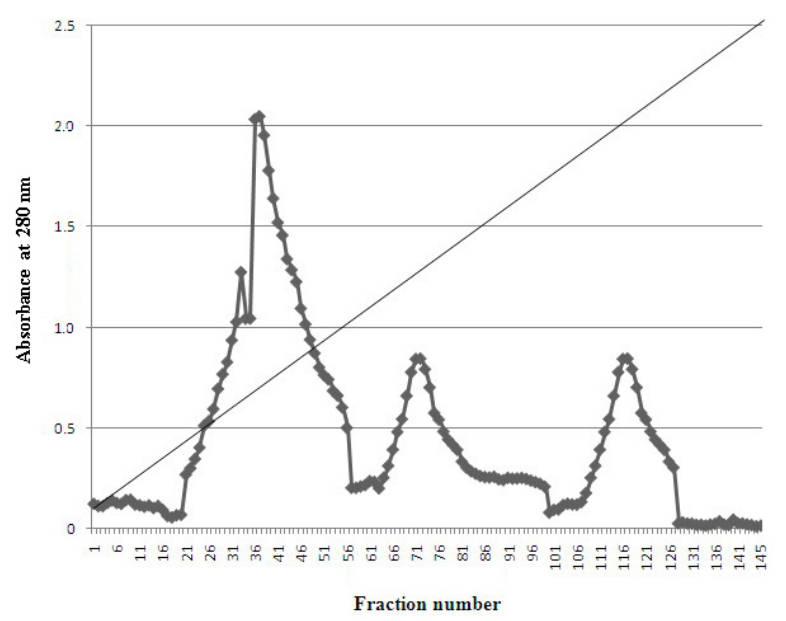

Figure 4. Ion-exchange chromatography of amniotic fluid on a DEAE-Sephacel column $(2.6 \times 16 \mathrm{~cm})$. The column was pre-equilibrated with $0.05 \mathrm{M}$ Tris- $\mathrm{HCl}, \mathrm{pH} 8.0$, at flow rate of $0.2 \mathrm{~mL} / \mathrm{min}$ and then eluted with a linear gradient of $0-0.5 \mathrm{M} \mathrm{NaCl}$. 
An aliquot of $25 \mathrm{mg}$ of the lyophilized protein from the DEAE bound at $0.1 \mathrm{M} \mathrm{NaCl}$ was dissolved in $0.05 \mathrm{M}$ Tris- $\mathrm{HCl}, \mathrm{pH} 8.0$, and $0.2 \mathrm{M} \mathrm{NaCl}$ and loaded onto a Sephadex G-75 $(1.6 \times 125 \mathrm{~cm})$ column pre-equilibrated in the same buffer. Fractions were collected at a flow rate of $6 \mathrm{~mL} / \mathrm{h}$ and monitored at $280 \mathrm{~nm}$. Figure 5 shows the elution profile of the Sephadex G-75 chromatography, and SDS-PAGE (10\%, inset) shows DEAE-Sephacel fractionated protein at $0.1 \mathrm{M} \mathrm{NaCl}$ and purified protein from the Sephadex G-75 column. The single band from the gel was cut, trypsin digested and analyzed by ESI-Q-TOF/MS. Figure 6 shows the MS profile of the purified protein, and the peptides matched with HPBP.

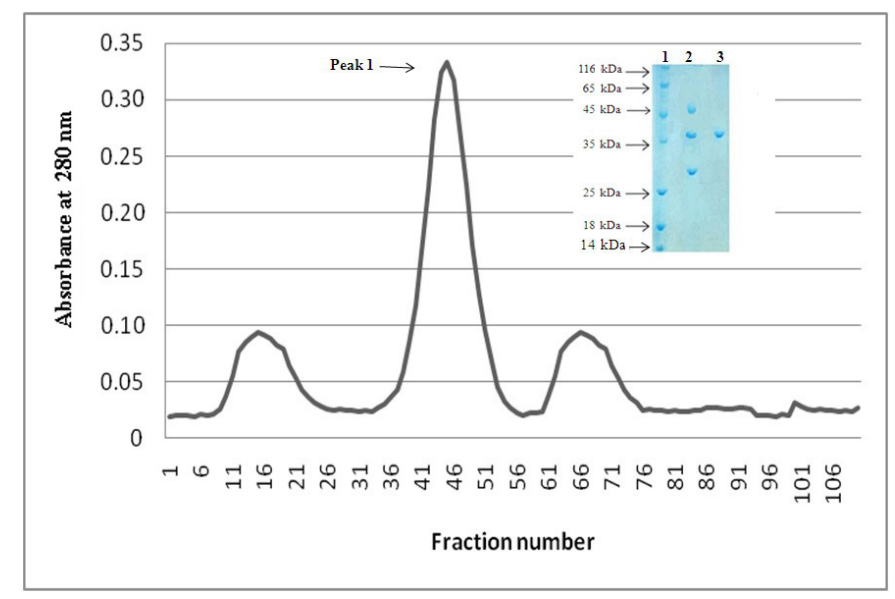

Figure 5. Elution profile of Sephadex G-75 $(1.6 \times 125 \mathrm{~cm})$ equilibrated in $0.05 \mathrm{M}$ Tris- $\mathrm{HCl}, \mathrm{pH} 8.0$, and $0.2 \mathrm{M}$ $\mathrm{NaCl}$, flow rate of $6 \mathrm{~mL} / \mathrm{h}, 2-\mathrm{mL}$ fractions. SDS-PAGE was performed on $10 \%$ polyacrylamide gels, and proteins were stained with colloidal Coomassie blue (G-250). Lane $1=\mathrm{SDS}-\mathrm{PAGE}$ analysis. Lane $2=$ Molecular mass markers. Lane 3 = DEAE-Sephacel, 0.1 M NaCl. Purified protein from Sephadex G-75.

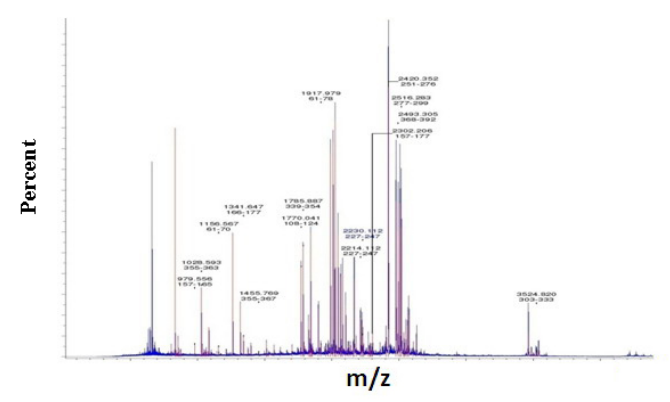

Human phosphate binding protein (HPBP) Apo-lipoprotein:

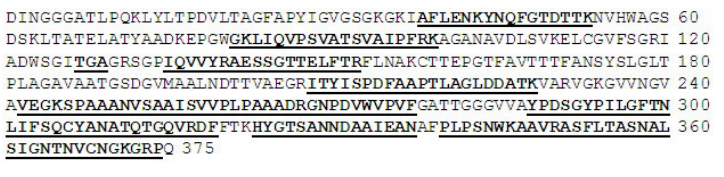

Figure 6. Mass spectrum of purified protein and peptides matched with human phosphate binding protein. 
HPBP is a novel member of the DING family of proteins, which are likely ubiquitous in eukaryotes. In humans, DING protein had been identified from synovial fluid of rheumatoid arthritis (Hain et al., 1996; Blass et al., 1999), breast cells (Belenky et al., 2003) and kidney epithelial cells (Kumar et al., 2004), but the first structure was deduced from the HPBP concomitantly purified with PON1 from human serum (Morales et al., 2006). The structure clearly showed a relationship between HPBP and ABC (ATP binding cassette transmembrane) transporters in prokaryotes. The role of DING protein in humans as an inorganic phosphate scavenger may protect against cardiovascular disease such as atherosclerosis (Dorozhkin and Eppe, 2002; Amann et al., 2003). Interestingly, it has also been shown that this protein prevents kidney stone formation by inhibiting calcium phosphate precipitation (Kumar et al., 2004).

We report here for the first time the use of proteomics in targeting and identifying human phosphate binding apolipoprotein from amniotic fluid. The use of proteomics-based purification and subsequent characterization through ESI-Q/TOF is found to be a reliable, quick and high throughput method of purifying HPBP, a member of the DING protein family.

\section{ACKNOWLEDGMENTS}

We are grateful to Dr. S. Mittal H.O.D., Department of Obstetrics and Gynecology, AIIMS, New Delhi, India, for providing well-characterized amniotic fluid samples. M. Alam thanks the Indian Council of Medical Research (ICMR) for granting a fellowship.

\section{REFERENCES}

Adams L, Davey S and Scott K (2002). The DING protein: an autocrine growth-stimulatory protein related to the human synovial stimulatory protein. Biochim. Biophys. Acta 1586: 254-264.

Amann K, Tornig J, Kugel B, Gross ML, et al. (2003). Hyperphosphatemia aggravates cardiac fibrosis and microvascular disease in experimental uremia. Kidney Int. 63: 1296-1301.

Angal S and Dean PD (1977). The effect of matrix on the binding of albumin to immobilized Cibacron Blue. Biochem. J. 167: 301-303.

Belenky M, Prasain J, Kim H and Barnes S (2003). DING, a genistein target in human breast cancer: a protein without a gene. J. Nutr. 133: 2497S-2501S.

Berna A, Bernier F, Chabrière E, Perera T, et al. (2008). DING proteins; novel members of a prokaryotic phosphatebinding protein superfamily which extends into the eukaryotic kingdom. Int. J. Biochem. Cell Biol. 40: 170-175.

Blass S, Engel JM and Burmester GR (1999). The immunologic homunculus in rheumatoid arthritis. Arthritis Rheum. 42: 2499-2506.

Bradford MM (1976). A rapid and sensitive method for the quantitation of microgram quantities of protein utilizing the principle of protein-dye binding. Anal. Biochem. 72: 248-254.

Campbell S and Lees C (2000). Obstetrics by Ten Teachers. 17th edn. Arnold, London.

Chevallier B, Lagarde A, Degrelle H, Belaisch-Allart J, et al. (1998). Insulin-like growth factor binding protein 1 level in amniotic fluid: correlation with birth weight. Biol. Neonate 73: 404-406.

Dorozhkin SV and Epple M (2002). Biological and medical significance of calcium phosphates. Angew. Chem. Int. Ed. Engl. 41: 3130-3146.

Dursun P, Demirtas E, Bayrak A and Yarali H (2006). Decreased serum paraoxonase 1 (PON1) activity: an additional risk factor for atherosclerotic heart disease in patients with PCOS? Hum. Reprod. 21: 104-108.

Fokine A, Morales R, Contreras-Martel C, Carpentier P, et al. (2003). Direct phasing at low resolution of a protein copurified with human paraoxonase (PON1). Acta Crystallogr. D. Biol. Crystallogr. 59: 2083-2087.

Gorg A, Postel W, Gunther S, Weser J, et al. (1988). Approach to stationary two-dimensional pattern: influence of focusing time and immobiline/carrier ampholytes concentrations. Electrophoresis 9: 37-46.

Gorg A, Postel W, Friedrich C, Kuick R, et al. (1991). Temperature-dependent spot positional variability in twodimensional polypeptide patterns. Electrophoresis 12: 653-658. 
Gorg A, Obermaier C, Boguth G, Csordas A, et al. (1997). Very alkaline immobilized pH gradients for two-dimensional electrophoresis of ribosomal and nuclear proteins. Electrophoresis 18: 328-337.

Hain NA, Stuhlmuller B, Hahn GR, Kalden JR, et al. (1996). Biochemical characterization and microsequencing of a 205-kDa synovial protein stimulatory for T cells and reactive with rheumatoid factor containing sera. J. Immunol. 157: 1773-1780.

Harel M, Aharoni A, Gaidukov L, Brumshtein B, et al. (2004). Structure and evolution of the serum paraoxonase family of detoxifying and anti-atherosclerotic enzymes. Nat. Struct. Mol. Biol. 11: 412-419.

Heizmann CW (1999). Ca ${ }^{2+}$-binding S100 proteins in the central nervous system. Neurochem. Res. 24: 1097-1100.

Kumar V, Yu S, Farell G, Toback FG, et al. (2004). Renal epithelial cells constitutively produce a protein that blocks adhesion of crystals to their surface. Am. J. Physiol. Renal Physiol. 287: F373-F383.

Lotgering FK and Wallenburg HC (1986). Mechanisms of production and clearance of amniotic fluid. Semin. Perinatol. 10: $94-102$.

Morales R, Berna A, Carpentier P, Contreras-Martel C, et al. (2006). Serendipitous discovery and X-ray structure of a human phosphate binding apolipoprotein. Structure 14: 601-609.

Morales R, Berna A, Carpentier P, Contreras-Martel C, et al. (2007). Discovery and crystallographic structure of human apolipoprotein. Ann. Pharm. Fr. 65: 98-107.

Park SJ, Yoon WG, Song JS, Jung HS, et al. (2006). Proteome analysis of human amnion and amniotic fluid by twodimensional electrophoresis and matrix-assisted laser desorption/ionization time-of-flight mass spectrometry. Proteomics 6: 349-363.

Rabilloud T, Valette C and Lawrence JJ (1994). Sample application by in-gel rehydration improves the resolution of twodimensional electrophoresis with immobilized $\mathrm{pH}$ gradients in the first dimension. Electrophoresis 15: 1552-1558.

Renault F, Chabriere E, Andrieu JP, Dublet B, et al. (2006). Tandem purification of two HDL-associated partner proteins in human plasma, paraoxonase (PON1) and phosphate binding protein (HPBP) using hydroxyapatite chromatography. J. Chromatogr. B Analyt. Technol. Biomed. Life Sci. 836: 15-21.

Rochu D, Renault F, Clery-Barraud C, Chabriere E, et al. (2007a). Stability of highly purified human paraoxonase (PON1): association with human phosphate binding protein (HPBP) is essential for preserving its active conformation(s). Biochim. Biophys. Acta 1774: 874-883.

Rochu D, Chabriere E and Masson P (2007b). Human paraoxonase: a promising approach for pre-treatment and therapy of organophosphorus poisoning. Toxicology 233: 47-59.

Schmidt H, Schmidt R, Niederkorn K, Gradert A, et al. (1998). Paraoxonase PON1 polymorphism leu-Met54 is associated with carotid atherosclerosis: results of the Austrian Stroke Prevention Study. Stroke 29: 2043-2048.

Strong TH Jr, Hetzler G and Paul RH (1990). Amniotic fluid volume increase after amnioinfusion of a fixed volume. Am. J. Obstet. Gynecol. 162: 746-748.

Travis J, Bowen J, Tewksbury D, Johnson D, et al. (1976). Isolation of albumin from whole human plasma and fractionation of albumin-depleted plasma. Biochem. J. 157: 301-306.

Tsangaris GT, Kolialexi A, Karamessinis PM, Anagnostopoulos AK, et al. (2006). The normal human amniotic fluid supernatant proteome. In Vivo 20: 479-490.

Verburg BO, Geelhoed JJ, Steegers EA, Hofman A, et al. (2007). Fetal kidney volume and its association with growth and blood flow in fetal life: The Generation R Study. Kidney Int. 72: 754-761.

Whitfield CR and Ritche JWK (1995). The Fetus, Placenta \& Amniotic Fluid. Dewhurst's Text book of Obstetrics and Gynaecology for Post Graduates. Blackwell Scientific Publication, London. 